\title{
Primary Healthcare meta-evaluation in Brazil: Lessons learned from the external assessment of the program to improve primary healthcare access and quality.
}

Danila Augusta Accioly Varella Barca ( $\nabla$ danilabarca80@gmail.com )

Federal University of Rio Grande do Norte

Paulo de Medeiros da Rocha

Federal University of Rio Grande do Norte

Cláudia Santos Martiniano

State University of Paraíba

Lygia Maria de Figueiredo Melo

Escola de Saúde da Universidade Federal do Rio Grande do Norte

Marize Barros de Souza

Escola de Saúde da Universidade Federal do Rio Grande do Norte

Nadja de Sá Pinto Dantas Rocha

Federal University of Rio Grande do Norte

Osvaldo de Góes Bay Junior

Federal University of Rio Grande do Norte

Themis Xavier de Albuquerque Pinheiro

Federal University of Rio Grande do Norte

Ardigleusa Alves Coelho

State University of Paraíba

Severina Alice da Costa Uchôa

Federal University of Rio Grande do Norte

\section{Research Article}

Keywords: Health Evaluation, Meta-evaluation, Primary Health Care

Posted Date: March 7th, 2022

DOI: https://doi.org/10.21203/rs.3.rs-1402288/v1

License: @) (1) This work is licensed under a Creative Commons Attribution 4.0 International License. Read Full License 


\section{Abstract}

Introduction: The Primary Healthcare Access and Quality Improvement Program (PMAQ-AB) implemented in 3 evaluation cycles (2011-2019) represents a turning point in the performance assessment of Primary Healthcare (PHC) in Brazil.

Methods: A cumulative meta-evaluation of the $P M A Q-A B$ External Assessment (Avaliação Externa do $P M A Q-A B-A E / P M A Q-A B$ ) using the qualitative Case Study method. The matrix of indicators was prepared based on the 4 principles of the Joint Committee on Standards for Educational Evaluations (utility, feasibility, propriety and accuracy) articulated to each of the 6 stages of the evaluation proposed by the Centers for Disease Control and Prevention. Triangulation of collection methods (document analysis, interview and focus group) and participants (managers, professionals and evaluators) and Bardin's content analysis were implemented.

Results: The "Involvement of Stakeholders" presented agreement in the instances of the Unified Health System, expanding adhesion of the municipalities in the cycles, credibility of the evaluator and conciliation by the federal government in the interests of certification of the municipalities and of research by the universities as strengths; while the absence of users in the decision-making processes of formulating and executing the program as a weakness. The "Program Description" was positive in the consistency of the AE/PMAQ-AB with the National Primary Care Policy/2011. The "Assessment Design" portrayed the Brazilian PHC and construction of comparable standards and certification criteria. The use of information technology, logistics and guidelines for training the interviewers gave the collection homogeneity, pointing to the usefulness and feasibility. The "Systematization and Analysis of Evidence" had the online validation systems, offer of micro data, availability of electronic reports to stakeholders as strengths, but there were weaknesses in the methodology transmission to municipal managers, incipient strategies of technical empowerment for interpreting and applying the results, in turn negatively impacting the "Justification of Conclusions" dimension. The utility of $A E / P M A Q-A B$ prevailed in "Sharing Lessons Learned" for an assessment culture in management, services, and academia.

Conclusion: The meta-evaluation presents a systemic view of the $A E / P M A Q-A B$, helping managers and professionals in the PHC assessment process. It raises awareness of user engagement in policy and program assessments, making them more plural, participatory and democratic.

\section{Background}

From the perspective of health as well-being, Primary Healthcare (PHC) occupies a central position in current health system reforms. Nations which assumed PHC as a guide for health policies from the perspective of comprehensiveness, intersectorality and quality obtained gains in improved health indicators, greater efficiency and quality in care, with more equity $[1,2]$ and are in better positions to reach all Sustainable Development Goals (SDGs), not just Health $[3,4]$.

The Unified Health System (Sistema Único de Saúde - SUS) in Brazil was created by the Federal Constitution in 1988 based on the principles of Universality, Equity and Comprehensiveness, and is financed by general taxation with the provision of healthcare for all [5]. The assessment of 30 years of the SUS in 2018 revealed expanding coverage reaching 75\% of the population, expanded supply and human resources, access and use of services [6], improvement in morbidity and mortality indicators, increased equity, efficiency and user satisfaction ${ }^{7}$. However, challenges of underfunding, regulation of the relationship with the private sector, complexity of the epidemiological profile, great social inequalities and heterogeneity in the quality of PHC with regard to resolution, access to first contact, qualified professionals and computerization [7] among the 5,570 Brazilian municipalities persist [6, 7].

PHC expansion with its enormous capillarity due to the Brazilian territorial dimension and the wealth of experiences in care, in teaching and in the management of the health system [8] opened institutional spaces for its evaluation from the 1990s onwards.

The discussion on the topic of Public Policy Assessment has been consolidating itself as an essential strategy for improving programs aimed at society with a view to improving the quality of life and reducing social inequalities. The Assessment field has its origins in accountability and program control [9].

The advancement in the development of public health policies and programs in both the world and in Brazil requires knowledge and initiatives on the need to carry out assessments which include analyzing the design, implementation, results and impacts of actions undertaken by governments [10]. Specifically, the assessments of the Brazilian PHC were associated with a political and social context marked by a reduction in expenditures and investments in the health sector vis a vis pressures for the need for greater efficiency; advancement in democracy with demanding guidelines, pressure to expand social programs in the face of increasing social inequalities and demand for results by international funding agencies [11].

Thus, two robust initiatives in the SUS were encouraged by the Federal Government aiming at institutionalized assessment in PHC: the Baseline Studies (Estudos de Linha de Base- ELB) of the Expansion and Consolidation of Family Health Project (Projeto de Expansão e Consolidação da Saúde da Família $P R O E S F)$ carried out in 2005, which sought to make a diagnosis of the epidemiological standard and the organization of services in 168 Brazilian municipalities with more than 100 thousand inhabitants [12]; and the Primary Healthcare Access and Quality Improvement Program (PMAQ- $A B)$ implemented in 2011 through three progressive cycles of continuous improvement $(2011 / 2012,2013 / 2014,2015 / 2019)$ [13].

The PMAQ-AB innovates by opening PHC funding in line with international references on the P4P (pay-for-performance) model [14], however it ties pay-forperformance with incentives to municipal management $[5,14]$ and not to direct remuneration to professionals. Measuring the effectiveness of the Primary Care Teams' (Equipes de Atenção Básica - Eq-AB) actions with the measurement of quality standards that could be comparable at different levels (national, regional and local) involved rounds of self-assessment and the $A E / P M A Q-A B$ [14]. The new financing form aimed to contribute to overcoming obstacles and challenges related to the infrastructure and operating conditions of health units, the high turnover of professionals, the low integration of PHC with care networks and the precariousness of information technologies to support decision-making processes $[4,15]$. 
In this context, the induction carried out by the PMAQ-AB occurs in the knowledge production about PHC in the SUS, the result of government initiatives by the Ministry of Health, interest of state and municipal managers and effective participation of academia. The three $P M A Q$ cycles generated and are still generating numerous studies which describe and discuss the PHC assessment [16].

With the publication of the new National Primary Healthcare Policy [17] in 2017, setbacks occurred within the scope of Brazilian PHC related to the flexibility of population coverage and segmented access to care, impacting the Family Health Strategy [18, 19], as well as changes in its funding model, leading to the termination of the PMAQ-AB and its replacement by the "Previne Brasil" program in November 2019 [20, 21].

Assessment is a formal intervention which aims to improve decisions [22]. The intervention requires relevance (answers to the problems of interest to decision-makers), merit (presents the potential to improve decisions) and credibility (the process quality and of the information produced), providing evidence of points which need to be adjusted in response to the interests of the interested parties, contributing to increase the possibilities of using its results $[22,23]$.

In this sense, it is necessary to evaluate the assessment quality by carrying out a meta-evaluation, which should seek to enrich the process, making it a space for reflecting on and improving studies and practices, considering the contextual aspects of each situation under analysis. To this end, assumptions will guide the basis for analyzing the quality of assessments [24] through the description, judgment and synthesis processes of a study [25, 26].

The Centers for Disease Control and Prevention (CDC) presented a strategy in 2011 by launching an orientation guide which aims to help managers, public or private health professionals to practically design and implement assessment on a daily basis [27]. The guidelines are based on the Framework for Program Evaluation in Public Health: A Checklist of Steps and Standards, placing the adherence of the 4 principles/standards (Usefulness, Feasibility, Property, Accuracy/Precision) of the Joint Committee on Standards for Educational Evaluation (JCSEE) [28] as fundamental to the 6 stages of the CDC evaluation (stakeholder involvement, program description, evaluation design, credibility of evidence, justifiable conclusions, sharing of results and lessons learned) to increase cultural competence in health evaluation $[29,30]$. These guidelines are considered important requirements capable of systematically and systemically structuring mechanisms to conduct a meta-evaluation.

The vast field of PHC conducive to evaluations needs to advance in meta-evaluation studies as a way of improving the judgment on the value of the conducted assessments. The $A E / P M A Q-A B$ accumulated numerous assessment experiences in the three cycles resulting from territorial diversity, the capacity for structure and management and the integration between academia, tripartite management of the SUS and the health service.

Research on the topic "Meta-evaluation in Brazilian PHC" carried out in the "Virtual Health Library (Biblioteca Virtual em Saúde - BVS), Scientific Electronic Library Online (SciELO), Public Medical Literature Analysis and Retrieval System Online (PubMed), Scopus and Web of Science" databases found few metaevaluation studies [31-33] which consider the $A E / P M A Q-A B$ as an object. Such studies worked with health experiences developed at the municipal level and even used the theoretical framework of the JCSEE (at least one of the principles/quality standards).

The present study aims to carry out a cumulative, systematic and comprehensive meta-evaluation of the Brazilian national experience of the $A E / P M A Q-A B$ based on the link to the assessment steps described in the scope of the CDC recommendations (2011), with adherence to the JCSEE standards, and taking into account the temporality of the 03 evaluation cycles of the $P M A Q-A B(2011-2019)$. Its realization is justified by filling a gap in studies in this area, by its magnitude, uniqueness of performance assessment with a contribution to the certification process of municipalities aiming at the financial incentive for $\mathrm{PHC}$, in addition to the confluence of management and academia work in the Brazilian assessment experience. Thus, considering the international guidelines aimed at achieving the quality of the evaluations, it will analyze the strengths and weaknesses of the $A E / P M A Q-A B$ in order to propose recommendations for improving the assessments and meta-evaluations of $\mathrm{PHC}$ in the national and international scenarios.

\section{Method}

\subsection{Study type}

This is a meta-evaluation which consists of the description and judgment process of any assessment procedure, including the researchers [26]. The three cycles of the $A E / P M A Q-A B(2011-2019)$ were considered cumulatively. The Case Study method with a qualitative approach from the perspective of Yin (2005) [34] was implemented due to the possibility of exploring, describing and explaining a contemporary phenomenon in a natural context, being considered consistent with the meta-assesment [35]. A triangulation of informants and data collection techniques was performed for better understanding of the various angles of the study object.

\subsection{Theoretical model - Meta-evaluation methodology of the AE-PMAQ-AB}

The theoretical methodological model of the $A E / P M A Q-A B$ meta-evaluation Case Study was based on the quality standards of the Joint Committee on Standards for Educational Evaluation, crossed with the dimensions of the evaluation guided by the Centers for Disease Control and Prevention, with adaptation of criteria referring to evaluation principles/standards to the context of $A E / P M A Q$ and validated by evaluation specialists. The model diagram is shown in the Fig. 1 [36]:

Inserted Fig. 1

\subsection{Study context}


Fieldwork took place between July 2018 and December 2019 at the Department of Primary Care of the Ministry of Health (Departamento de Atenção Básica do Ministério da Saúde - $D A B / M S$ ) in Brasília, and at the central campuses of 6 Teaching and Research Institutions (Instituições de Ensino e Pesquisa IEPS) responsible for conducting the $A E / P M A Q-A B$.

\subsection{Study participants}

The sample was intentional with 54 participants; 07 were representatives of the $D A B / M S$ (01 coordinator and 06 technicians) and 47 of the 06 IEPS (06 coordinators and 41 researchers). The inclusion criterion was being part of the $A E / P M A Q-A B$ conduction team for at least 2 cycles and having remained throughout the 3rd cycle. The team of evaluators from an IEP that did not complete the 3rd cycle was excluded.

\subsection{Instruments and data collection technique}

The instruments/scripts were prepared according to the stages described in Fig. 2 (Script for Document Analysis, Script for Interviews and Script for the Focus Group) and are available at the link.

Inserted Fig. 2

With regard to document analysis, the documents were considered as communicative devices or a context of social relationships [37] as a specific way of understanding the reality studied, as identified in the Table 1. 
Table 1

- Documents researched and analyzed in a meta-evaluation study on the AE-PMAQ-AB, Brazil, 2018-2019.

DOCUMENT

\section{LINK}

http://189.28.128.100/dab/docs/publicacoes/geral/doc_tec_amq_portugues.pdf

https://bvsms.saude.gov.br/bvs/publicacoes/manual_instrutivo_pmaq_atencao_basica.pdf
TITLE

DESCRIPTION/TYPE

Technica

Evaluation to improve the quality of the

Family Health Strategy.

Instructional manual for Primary Care and NASF

teams: Primary

Healthcare

Access and

Quality

Improvement

Program

(PMAQ)

(2015-2017).

https://bvsms.saude.gov.br/bvs/saudelegis/gm/2015/prt1645_01_10_2015.html.

Ordinance no.

Technical

document/Ministry

of Health - $A M Q$

Technical

of Health -

$P M A Q / A B$

containing all the

constitutive steps.

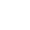

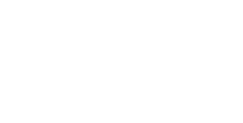

1645, of

October 2,

2015. Provides

for the Primary

Healthcare

Access and

Quality

Improvement

Program

(PMAQ-AB).

2015. Available

in: Accessed

on: 10 jun.

2020

http://189.28.128.100/dab/docs/portaldab/documentos/nota_metodologica_2_ed_ab_absb_certificacao.pdf

https://retratos.navi.ifrn.edu.br/

http://pmaq.lais.huol.ufrn.br/relat_analiticos

\section{.}

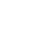

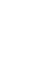

$\sqrt{2}$

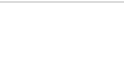

PHC portraits

\section{Methodological Scoring for the Certification of Primary Care}

Teams/Primary

Healthcare

Access and

Quality

Improvement

Program

$(P M A Q-A B)$ :

Third cycle.

Brasília:

Ministry of

Health, 2018.

\section{$P M A Q$ \\ Analytica}

PHC portraits
document/Ministry

\section{Ministerial}

Ordinance/Ministry

of Health

Technical document

with the

methodology

applied for the

certification of

teams.

Online access

platform for

analytical reports.

Online access platform containing the availability of

data from the 3rd

Cycle of the $P M A Q$ $A B$ in the format of useful information for monitoring and managing primary care.

https://aps.saude.gov.br/ape/pmaq/ciclo3/

External Assessment

Microdata

Data obtained by $A E / P M A Q-A B$ at its lowest disaggregation level.

Source: Research collection (2018-2019).

\subsection{Data analysis}

The data obtained in the study with the 3 techniques were analyzed using Bardin's Content Analysis [38] method, which consists of a detailed deepening with the use of various methods addressed regarding an analysis of discourses and other scientific evidence models. Figure 03 presents the data analysis stages. 


\subsection{Ethical aspects}

The project was approved by the Research Ethics Committee of the Onofre Lopes University Hospital of the Federal University of Rio Grande do Norte, under approval through CAEE number: 84537418.1.0000.

\section{Results}

\section{Dimension 1 - Stakeholder engagement}

\section{- Utility}

With regard to the criterion of "Identification of the main stakeholders", there was a definition on the identification and agreement with key actors to carry out the $A E / P M A Q-A B$ including the Tripartite Intermanager Commission (Comissão Intergestores Tripartite- CIT), the Ministry of Health represented by the Department of Primary Healthcare, the National Council of State Health Secretaries (Conselho Nacional de Secretarias Estaduais de Saúde - CONASS), the National Council of Municipal Health Secretaries (Conselho Nacional das Secretarias Municipais de Saúde-CONASEMS), Teaching and Research Institutions (IEPS), municipal health managers and users. In relation to the managing instances, the Program's formal documentation demonstrates that:

The negotiation and agreement process of the three management spheres of the SUS that had several moments, in which the MS and the municipal and state managers, represented by the National Council of Municipal Health Secretariats (Conasems) and the National Council of State Health Secretaries (Conass), respectively, debated and formulated solutions to enable a program design which could enable expanding access and improvement in the quality of primary healthcare throughout Brazil (p.7) [39].

In addition to identifying stakeholders, mechanisms were established to guarantee permanent participation in the $P M A Q-A B$. The induction of adhesion by municipal health managers was related to payment for performance and its implications for PHC funding, more specifically in the Primary Care Floor, as established by a specific ministerial decree.

However, this participation did not materialize in other stakeholder groups, health professionals or PHC users, resulting in a gap between "the intention and the gesture" because the $D A B / M S$ did not create institutional spaces for participation and social control.:

What I think could be improved in the $P M A Q$ is user participation, how to involve the National Health Council more, how to involve the councils, since one of the perspectives of the $P M A Q$ is the issue of transparency. [...]. There was little involvement in social control, it has been little in all cycles, I think there is no such... awareness, perhaps, awareness regarding the very communities of users where the $P M A Q$ itself is coming from [...] what is the value of this $P M A Q$ ? $(\mathrm{GF}-4)$

It is worth mentioning the recognition of the IEPS as a decisive stakeholder in the $A E / P M A Q-A B$, with scientific interests:

[...] University, it was a very interesting proposal, which we were already talking about in that perspective of a large Primary Healthcare database, the largest information center ever made. The first cycle would be the primary care census, never carried out in Brazil, of visiting all UBS. So, the institutions and the Ministry were very interested in bringing this together and achieving its objective, which was to establish a pay-for-performance program in Brazil. (GF - 7)

Regarding the criterion of "Evaluator's Credibility", the universities identified to conduct the external assessment fulfilled the requirements of evaluation expertise, familiarity with the context and with the assessment object, as shown below:

The choice of these universities which nucleated the process that now lead this $P M A Q$ process was largely due to their leadership in the opportunity to discuss the $P M A Q$, participation in the Primary Healthcare Research Network [...] They (the nucleating universities) were actively leading this debate in the ABRASCO Network and in the dialogue with the Ministry of Health. (E-5)

\section{Dimension 2 - Program description}

\section{- Accuracy}

The Standard was found in the "Formal Documentation" criterion of the $P M A Q-A B$, demonstrating its objectives and needs through the general characterization, organization of quality improvement cycles and operationalization phases:

The implementation phases of the Primary Healthcare Access and Quality Improvement Program is organized into four phases which complement each other and form a continuous improvement cycle of access and quality of PHC, namely: 1 - Adhesion and contractualization; 2 - Development; 3 - External assessment; 4 - Recontractualization (p.15) [40].

The $A E / P M A Q-A B$ has the greatest weight in the certification of $E q-A B$ for performance payment according to document analysis:

[...] The teams participating in the $P M A Q$ will be certified according to their performance, considering: a. External performance assessment of health teams and primary care management, [...] through verification of evidence for a set of predetermined standards [...] final certification grade: Implementation of self- 
assessment processes 10\%, Assessment of contracted indicators 30\%, External Assessment 60\% (p.33) [40].

In the "Context Analysis" criterion, there is coherence of the assumptions of the $A E / P M A Q-A B$ with the National Primary Healthcare Policy (Política Nacional de Atenção Básica - PNAB), considering the PHC assessment as the main guideline of the $M S$ to expand access and quality of actions and services, considering previous experience triggered by the PROESF Expansion and Consolidation Project:

The $P M A Q-A B$ is one of the main current guidelines of the $M S$ to execute public management based on inducing, monitoring and evaluating processes and measurable results, guaranteeing healthcare access and quality to the entire population [...] in the sense of adjusting the strategies foreseen in the $P N A B$ in the direction of recognizing the quality of PHC services offered to Brazilian society and stimulating the expansion of access and quality in services. (p.7) [39].

PMAQ has a lot to do with PROESF [...] a more elaborated, broader continuity of PROESF. [...] linked to a tradition of studying the assessment of Primary Healthcare in Brazil, [...] a work process that is well discussed, well evaluated, from a scientific point of view, of what should be done. (E-3)

\section{Dimension 3 - Assessment design}

\section{- Utility}

This Standard was found in the design of the $A E / P M A Q-A B$ referring to the "Impact of the Assessment" criterion, with the existence of mechanisms for monitoring the results of the performance assessment and certification of teams in each quality improvement cycle:

What I do know is that from the point of view of producing knowledge for us to know how primary healthcare is in Brazil, I think it is an effort of great merit [...] Never in the world has there been any quality program with the extension that PMAQ has; they say every time we went to events, someone always came to say that. It's only in Brazil that such a big thing is done. (E-6)

The orientation regarding the usefulness of essential and strategic quality standards is seen as a guiding element in the inductive process:

How to induce two thousand things at the same time, which is the average number of questions regarding the quality standard that we have in the $P M A Q$ ? [...] we want to induce, but we cannot communicate what to induce [...]. A number of standards that we called essential and strategic for primary healthcare, so, if we direct our gaze to these standards, maybe a little light will turn on, look, these are the most important ones, right, for quality in primary care [...]. (GF7)

\section{- Feasibility}

The feasibility for data collection was verified in the "Practical Procedures", developed with comprehensive logistics and standardized guidelines and instruments in Brazil:

It's great logistics [...] we call the municipality, we talk to the coordinator, we have the name of the reference professionals who will be interviewed, we know how to agree on times and days. So all this is very much agreed with the institution. So from there, we already feel the organization level and willingness to participate in the assessment. (GF-6)

In the criterion "Political Feasibility", it appears that the $A E / P M A Q-A B$ had the decisive support of the Federal Government:

The President (Dilma Roussef) demanded that the Ministry of Health approve an increase in the primary healthcare budget, that processes be developed to verify the quality, that it was not just more money for the municipalities to deceive the Federal Government [...] PMAQ arises in this context. (E-7)

The scientific knowledge production about PHC in the IEPS, and innovative technologies had repercussions on the SUS, justifying the investment, characterizing a positive "Cost-Effectiveness" relationship, according to the statement:

Today, we have some of the main researchers in the field of health gathered to evaluate the system, we have important structures established in some public universities [...] there is scientific density to really process this data, to really have a very consistent production within of primary care, so I think that in terms of cost-effectiveness, I think the PMAQ is quite valid for our SUS. (E-4)

\section{Dimension 4 - Systematization and analysis of evidence}

\section{- Utility}

It appears that data validation through the use of an electronic tool (tablets) in the "Relevant Information" criterion provided credibility at the collection time, gathering reliable evidence.

[...] Validation in the $A E$ instrument is related to filling in the fields (responses to the standards). In this case, the instrument itself is responsible for the validation. The validation criteria are: a) expected value for typing in the instrument; b) response size (number of characters); c) absence of information when the question "does not apply". (AD - Field Manual - Cycle 3) 


\section{- Accuracy}

The existence of arrangements in some places can be seen as a limitation in the data collection in the "Source of Reliable Information" criterion, seeking positive results in the assessment related to verification of the structures (equipment, physical installations). Thus, strategies were adopted in an attempt to minimize this "cosmetic makeup" (as called by the participants), such as the involvement of several professionals:

I think the fact that you involve several people in the research is an important element for us to try to reduce the chance of makeup [...] this nurse will be responsible for answering the work process questions. Who will be the structure, who will accompany the document? [...] So when you somehow manage to involve a whole team in the evaluating process, which is what they have been doing in terms of serving their population [...] you can reduce this risk [...]. (GF5)

The importance of training the interviewers for field work is verified with regard to "Valid Information", however the long interview time due to the size of the collection instrument was presented as a weakness, causing exhaustion among those involved, which may have compromised the quality of the responses:

[...] I don't know if it's clear to those who are answering what, in fact, they want to induce... it has a direct impact on the quality of this data as well... because it's extensive [...] because it's long, I think that everyone is very tired at the end after two hours of interviewing [...] of the person being interviewed not understanding what is being asked and the interviewee also runs a little more with those questions [...] I think that this impacts the quality of this information. (GF-7)

The importance of using information technology in the data collection process and in the information production, storage and treatment was recognized, meeting the criterion of "Systematic Information".

You imagine that a lot of paper was produced from that piece. It was a disgraceful piece of paper [...] Then you have to go over everything [...] you eliminate a series of research steps, and it gives credibility, agility. You can show the result within a year. [...] now there is no doubt that it is advantageous [...] If you have a program, a safe program, you can do that. I have no doubt that it advances. (E-3)

\section{Dimension 5 - Justification of the conclusions}

\section{- Utility}

The "Identification of Values" criterion was analyzed on the assumption that other elements of this analytical understanding are located in earlier parts of the text (identification of stakeholders, program description and assessment design).

Here, the analysis elements rest on characterizing how the interested parties made use of the $A E / P M A Q-A B$ results, by the variation of their interests identified in implementing the $P M A Q-A B$. Some fragments exemplify the findings containing the diversity of views of those involved, notably between the $M S$ and universities:

Universities have never had a role in certification [...]. We produce the data, send the information to the Ministry of Health [...] they made the decision with their technicians and scientific support to make the certification. But from that point on the universities took precedence in the use of the database for academic analysis [...] presentations at events, national and international debates on performance assessment, on incentives to pay for performance in the health network, which was an absolutely innovative strategy in the country until then. (E-5)

It appears that the municipal health departments (managers and teams) approached the use of data resulting from the $A E / P M A Q-A B$ differently (financing and inadequacies):

[...] What was the main argument of the municipalities? They are not against the $P M A Q$, they don't want to end the $P M A Q$, they don't want to weaken the $P M A Q[$ [... it's just that they say "look, okay if that's what you're saying I have to do, it's just that you don't fund it adequately" [...] they tell the Ministry, "'you don't fund it properly and you institute many rules that stifle my ability to give... to face it" ${ }^{m}$. The issue of financing, of the financing blocks, they enter this debate". (E-7)

\section{Dimension 6 - Sharing lessons learned}

\section{- Utility}

The "Impact of Assessment" criterion aims to institutionalize the evaluation culture, contributing to decision-making with evidence by inducing monitoring by stakeholders:

I think that the entire $P M A Q$ process in a way fostered the development of an evaluation culture. Both at the level of the health service and at the level of management, and even at the level of social control, because it has the opinion of users and everything else. It takes the evaluation culture to other higher levels, such as the health department, ministry of health [...] So by encompassing different actors, the $P M A Q$ is able to favor that this evaluation culture permeates these different actors" [.. .] So, this induces, but it does not guarantee that this will have continuity if this is not incorporated as a process by the 
teams. (GF-6) "Universities have become quite skilled and experienced in the challenge of policy formation, policy planning and implementation with the $P M A Q$. (E-5)

\section{- Property}

There is guidance to reinforce mechanisms for using the results in the "Dissemination of Results" criterion, valuing the potential for changes with the PHC teams:

This ends up becoming knowledge that is [...] shared, and from there it can generate new forms of behavior to take this knowledge to their bases, to their places. So, the $P M A Q$ is fantastic for knowledge production generation, and has very strong potential to change the behavior of professionals from the moment these results are known. (GF-5)

With regard to analytical reports, the $A E / P M A Q-A B$ design provided for its validity as a support element for management and teams, and a facilitator of reflection on the work of PHC; however, limitations were pointed out in the dissemination in a timely manner:

[...] This difficulty is an investment difficulty, we do not have a stronger IT development group at the Ministry to make this data available. It's just that we don't have a sufficient technical team to make this data timely [...] without technological investment, professional investment and team investment, it's practically impossible for us to do the things we propose, right? Which is to use these results in a timely manner [...]. (GF-7)

\section{Discussion}

The meta-evaluation carried out based on the CDC dimensions and prioritization of the JCSEE principles/standards, whose distribution was qualitatively varied in the different assessment stages, points to the existence of strengths and weaknesses in the $A E / P M A Q-A B$.

The "Stakeholder Engagement" dimension analyzed from the Utility principle/standard had as its strengths the interfederative agreement of the $P M A Q-A B$, with the involvement of the three instances in the tripartite agreement space of the SUS, meeting the interests of the Ministry of Health (certification of the teams) and the IEPS (research); and the credibility of the group of IEP evaluators, resulting from previous experiences with PHC assessment studies. However, the fragility of user engagement in the decision-making processes of formulating and executing the assessment was verified, characterizing little participation of social control.

Studies on the importance of stakeholder analyses have grown in recent decades, from its use in business evaluations to its more recent use in social policies, programs, projects and management in the health area [41], in line with the literature that identifies it as a basic step in the analysis process, demonstrating its importance [42]. Using a scoping review, L. Franco-Trigo et al. [43] show that integrated changes in healthcare systems are complex efforts that will require a planned engagement design based on the guidelines indicated in the theoretical construct (stakeholder analyses), as addressed in Reed et al [44].

The experience accumulated in the tripartite agreement processes in the SUS supported the discussion on the $P M A Q-A B$ in the three instances, innovating in the articulation between municipal management and health professionals [14]. For most of the interviewees in this research, adhesion to the $E q-A B$ shows decisive involvement in performance production, contributing to improve access and quality indicators, but fragile participation in the defense of their interests and in institutionalizing the evaluative culture recommended in the program.

Shortcomings were found with regard to PHC users in implementing more effective participation aimed at interacting with other stakeholders and identifying their needs. They were important in the role of interviewees in health units, but they had clear institutional limits, since their perception was not considered in the methodological design of the certification, which would contribute to a more pluralistic and emancipatory evaluative engagement according to pioneering studies by Baron and Monnier [45], Guba and Lincoln [46], Furtado and Vieira-da-Silva [47], who point to 4th and 5th generation assessments.

The "Evaluator's Credibility" criterion points to the discussion related to the assessment legitimacy from the perspective of technical-scientific rigor, contributing to its acceptance by interested parties. In this context of Brazilian PHC, from the $D A B / M S$, proponent and driver of the $P M A Q-A B$ (primary stakeholder) [44], the necessary confidence was evidenced regarding the adequate conditions gathered by the IEPs to obtain results with a high degree of credibility. In an integrative review of evaluative studies and their possible uses, Medeiros, Nickel and Calvo [48] indicate the importance of this credibility; as pointed out in the research by the objectivity component given by university researchers as a decisive guarantee in the local assessment process, reaffirming the political-institutional importance of the IEPS in the $A E / P M A Q-A B$ process, printing a true "quality seal" by legitimizing and attesting this assessment with scientific rigor [49].

The "Program description", best expressed in the document analysis, worked through the Accuracy principle/standard, considered the implementation context of the Family Health Strategy and presented consistency with the principles and guidelines of the National Policy for Primary Healthcare (2011). The $A E / P M A Q-A B$ gave greater weight to the assessment in the team certification process ( $60 \%$ of the goals), demonstrating potential in producing relevant information. The analysis of the Program context based on its description in the formal documents highlights the $A E / P M A Q-A B$ with the assessment of the team work processes, the units' infrastructure and the users' satisfaction as the main strategy of the MS for inducing improved access and quality of PHC services in response to the monitoring and assessment axis of the $P N A B$ [50]. Studies available in the literature analyze the induction mechanism (P4P) in the improvement of health actions/care and review international experiences [51-53]. There was increasing adherence of $E q-A B$ during the $P M A Q-A B$ 
(2011-2019) term; only $50 \%$ of the teams could participate in the 1 st cycle, while there was no limit for adherence in the two subsequent cycles, reaching 38,864 in the 3 rd cycle (89.5\%) of the total number of teams existing in the country in 2018 [4], therefore constituting significant coverage in view of the chronic underfunding of Brazilian PHC.

The Utility and Feasibility principles/standards guided the analysis of the "Assessment Design", in which the results presented a broad portrait of Brazilian $\mathrm{PHC}$, construction of quality standards comparable with defined criteria for certification of health teams, design of logistics and national guidelines for training conferred homogeneity in data collection. Political viability guaranteed the increase in the SUS budget aimed at PHC expansion, however it lost strength during the third cycle (2015-2018) with the removal of the President of the Republic and the implementation of economic austerity measures negatively impacting the conduct of the $P M A Q-A B$.

The $A E / P M A Q-A B$ design was considered by the interviewees as useful for achieving the Program's goals for achieving performance and certification of health teams, both in the temporal evolution and in the position of the teams in the three improvement cycles, considering the observation of quality standards (essential and strategic) and monitoring health indicators. Linking the design of the $A E / P M A Q-A B$ to the funding guarantee was decisive for PHC qualification, as shown by other studies [18-20]. The detailed description of these patterns was analyzed by Anjos et al. [14] and the indicators were studied by Kovacs [54], showing variations in quantity over the three improvement cycles (Cycle 1 -573, Cycle 2-893 and Cycle 3-648) and covering aspects related to structure, equipment and supplies, health management, care processes and morbidities [55]. If, on the one hand, a large number of indicators used to verify the standards made it possible to associate the $P M A Q-A B$ with favorable PHC results, on the other hand, a large number of indicators made monitoring and assessment difficult by managers and professionals [56], in addition to the collection requiring contribution of financial and technological resources as well as professionals, and also point to the need to validate the ability of these indicators to demonstrate the reality, their internal consistency and the quality of the evidence they can provide.

These results also show the limitations of the $A E / P M A Q-A B$ to face a set of deficiencies existing in the Brazilian PHC, such as lack of inputs, deteriorated equipment, and deficiencies in infrastructure. Furthermore, specific characteristics of low organizational capacity and autonomy in several Brazilian municipalities, in addition to the challenge of retaining and insufficient training of professionals appear in the studies by Saddi and Peckham [57] and Massuda [3]. Conrad and Perry [53] reviewed studies on pay for performance, and already indicated the need to understand this mechanism as an important tool for inducing improvements in healthcare quality, but with the need for articulation with other quality inducers, for example, structure organizational. This combination of factors unfavorably contributed to improving these standards and indicators, revealing the insufficiency of the $A E / P M A Q$ to promote the necessary changes in isolation.

In this direction, Facchini et al. [19] analyzed how the advances of recent years were not enough to overcome all the challenges in evaluating PHC, and that operationalizing the concept of care quality remains a complex and essential task for developing policies and interventions in PHC.

Still in the "Assessment Design" dimension, an important point is the feasibility with regard to "Practical Procedures", as the results highlighted elements that converge towards the valuation of a well-planned process, articulating different actors at different times and spaces. This implied in articulation strategies and agreements between interested parties, and configured a robust preparation that preceded performing the $A E / P M A Q-A B$ in the three developed cycles, contributing to avoid or minimize distortions in the information collection. In this sense, they are in line with the studies by Uchoa et al. [31], and by Cavalcanti, Fernandez and Gurgel Júnior [49], which highlight the institutional role played by the IEPs in the various activities that involved the fieldwork of the research, resulting in a national standardization of procedures, and particularly the information technology resource which is useful in training researchers and interviewers, homogeneously collecting and validating data throughout the country.

The political and personal decision of the president of the country was relevant in the results referring to the "Political Feasibility" criterion to make it possible to obtain reliable information on primary healthcare conditions in order to guide decisions about the increase in the SUS budget referring to PHC and that it was linked to the performance of the teams. Thus, the conditions were given to prioritize improvement in access and the quality of the service offered. In this context, and allied to the program design, conditions and effects were created which favored the continuity of the PHC assessment policy, conducted by a technical team from the MS.

There were significant political and economic changes in Brazil in the third cycle of the assessment program (2015-2019). The crisis scenario reached the change in the federal government and the implementation of economic austerity measures, which had a strong impact on health policies and programs, including the $P M A Q-A B$, according to recent studies by Massuda [3] and Castro [5].

The "Systematization and Analysis of Evidence" analyzed by Utility and Accuracy had as its strengths the development of online validation systems, offering micro data, online reports made available by the $M S$ with access to different stakeholders. However, there were weaknesses, especially in cycle 1 , in the possible lack of control over the existence of "makeup" developed in some places, serving as a warning sign for researchers. In addition, the certification methodology transmission was questioned by municipal managers and incipience in the empowerment of technical capacity strategies and partnerships with municipal managers and professionals for interpreting and applying the results, negatively impacting the "Justification of Conclusions" dimension.

Tomasi et al. [19] detail how the assessment procedures were included in the $A E / P M A Q-A B$ and how the collection instruments were structured and standardized to meet the objectives, with guidance from the technical areas of the $M S$ and available for consultation on the institutional website. Cavalcanti, Fernandez and Gurgel Júnior [49] highlight the use of the electronic module (online) filled in by managers and teams in order to complement information. The obtained data security indicates rigor in the collection and validation process with the use of tablets, speeding up feeding of the centralized database in the MS. Data control was highlighted by Facchini et al. [19] as a result of the computerized management system developed by the 
information technology team at the Federal University of Rio Grande do Norte, allowing "real-time checking" of the consistency of responses and controlling the interview time.

Taking into account the accuracy based on the "Source of Reliable Information" criterion, it was found that professional nurses responded to more than $90 \%$ of the interviews [40], as they have the requirements recommended in the documentary guidelines in order to add more knowledge about the teamwork processes. On the other hand, physicians had incipient participation, showing no leadership and little knowledge about the work organization. Critical aspects related to training professionals in the PHC area, and work management (precariousness and turnover) were evidenced, compromising the information reliability. This finding is also consistent with the research by Saddi and Peckham [57], which demonstrates the need for greater investments in the organizational capacity of health units to provide better performance for their professionals.

The criticisms regarding the possible "makeup" developed in some places served as a warning signal for researchers and for national management. However, analyzes such as those by Cavalcanti, Fernandez and Gurgel Júnior [49] address that this occurrence of "false scenarios" to obtain good performances did not prevent the finding that the $P M A Q-A B$ induced changes in the way of working in PHC.

Utility is a recurring pattern in the "Justification of Conclusions" dimension, as in the other dimensions. The "Identification of Values" regarding the use of the findings of the $A E / P M A Q-A B$ varied according to the diversity of views of the stakeholders involved. The challenge of communicating assessment results was aligned with the recognized obstacle in the scope of health assessment, and begins with the interest and involvement of those interested in data analysis and interpretation. In the direction of these values, the use of the data obtained for decision making for the $M S$ met the objective of certification and transfer of financial resources to the municipalities, while the universities valued the use of the database for studies on health assessment and PHC, with publications of scientific articles, elaboration of dissertations and theses and dissemination in scientific events. The interest of the municipalities turned to the use of the resources received in a new modality (Quality - PAB/Variable), allowing to introduce improvements in the health units, in addition to implementing financial stimuli to the professionals of the teams. Moreover, to primarily generate training spaces for analysis of the standards reached by each health unit [58]. In this sense, it provides what we can call a decentralized assessment, as its findings are feedback for managers at the federal, state and municipal levels [59]. In addition, the findings and recommendations themselves were used to improve the successive cycles of the $P M A Q-A B$ (2011 to 2019).

Advances towards the "institutionalized assessment" were pointed out in the "Sharing lessons learned" dimension worked on in the Utility and Property principles/standards, considering the definitions of the pioneering study by Hartz [60]. In research on the reality of research organizations and agencies, Felisberto et al. [61] discuss the potential of increasing local capacity in promoting institutional changes that favor the assessment routine. There is a need for greater knowledge about the motivations of frontline professionals in the municipalities, as well as whether changes have occurred with the $P M A Q-A B$ in health units from institutionalizing more permanent evaluative standards [55]. The existence of a healthy cooperation between the IEPS and the MS expanded the existing institutional capacities, guaranteeing implementation of the $P M A Q-A B$ in its three cycles [48].

The potential for using the $A E / P M A Q-A B$ results is verified in the "Dissemination of Results" domain, with local variations of employed mechanisms given the diversity of structures, with recognition that municipal managers, teams and the population are end users of these data. In addition to providing the data presented in analytical reports, it is necessary that both the MS, the IEPs and state administrations offer logistical and technical support for data interpretation, providing conditions for analysis and interpretation, generating reflections for better intervention in each specific reality. In the dissemination of the results, the usefulness of holding national meetings to monitor the assessment was noticed as one of the strategies, in addition to dissemination production and publishing reports online.

\section{Conclusion}

The meta-evaluation study achieved the objective of identifying the strengths and weaknesses of the $A E / P M A Q-A B$ in the three evaluation cycles using the reference standards of the JCSEE and the CDC. As an academic contribution, it innovates from the perspective of meta-evaluation to focus on the systemic view of the evaluation, identifying the favorable and unfavorable aspects in each of its 6 stages. In practice, it will help managers and professionals to improve the PHC assessment process based on the meta-evaluation of an external assessment of such scope and relevance in the SUS, despite the end of the PMAQ-AB in 2019, this study presents results that can be considered in elaborating assessment and meta-evaluation of PHC in both the national and international scenarios. It raises awareness in the social contribution of the need to engage users in the evaluation processes of public policies and programs, making them more plural, participatory and democratic. New PHC meta-evaluation studies should be directed to update the assessment scenario in Brazil, and in this sense the use of multidimensional strategies contemplating quantitative and qualitative aspects is essential.

\section{Abbreviations}

BVS - Biblioteca Virtual em Saúde (Virtual Health Library)

CDC - Center for Disease Control and Prevention

CIT - Comissão Intergestores Tripartite (Tripartite Intermanager Commission)

CONASEMS - Conselho Nacional das Secretarias Municipais de Saúde (National Council of Municipal Health Secretaries)

CONASS - Conselho Nacional de Secretarias Estaduais de Saúde (National Council of State Health Secretaries)

Page $11 / 17$ 
DAB - Departamento de Atenção Básica (Primary Healthcare Department)

ELB - Estudos de Linha de Base (Baseline studies)

Eq-AB - Equipes de Atenção Básica (Primary Healthcare teams)

IEP - Instituições de Ensino e Pesquisa (Teaching and Research Institutions)

JCSEE - Joint Committee on Standards for Educational Evaluation

MS - Ministério da Saúde (Ministry of Health)

NASF - Núcleos de Apoio à Saúde da Família (Family Health Support Centers)

P4P - Pay-for-performance

PHC - Primary Healthcare

PMAQ-AB - Programa de Melhoria do Acesso e da Qualidade da Atenção Básica (The Primary Healthcare Access and Quality Improvement Program)

PNAB - Política Nacional de Atenção Básica (the National Primary Healthcare Policy)

PROESF - Projeto de Expansão e Consolidação da Saúde da Família (Expansion and Consolidation of Family Health Project)

PubMed - Public Medical Literature Analysis and Retrieval System Online,

SciELO - Scientific Electronic Library Online

SDO - Sustainable Development Objective

USB - Unidade de Saúde Básica (Basic Health Units)

\section{Declarations}

\section{Ethics approval and consent to participate}

Approved by research ethics committee of Onofre Lopes University Hospital - Federal University of Rio Grande do Norte (CAAE: 84537418.1.0000.5292).

\section{Consent for publication}

Not applicable.

\section{Availability of data and materials}

The dataset that supports the conclusions of this article is available in the repository Figshare, https://doi.org/10.6084/m9.figshare.16531275.v2

\section{Competing interests}

All other authors declare they have no conflict of interest.

\section{Funding}

This work was supported by Department of Primary Care of the Ministry of Health (Brazil) and by National Council for Science and Technology Development (http://cnpq.br/), Process 306024 / 2018-7. The funders had no role in study design, data collection and analysis, decision to publish, or preparation of the manuscript.

\section{Authors' contributions}

DAAVB, SACU, PMR and TXAP planned the study. DAAVB, OGBJ, CSM, MBS, LMFM and AAC performed study selection and data extraction, and performed analysis and synthesis of results. All authors contributed to writing the manuscript. DAAVB, SACU and PMR critically reviewed the manuscript. All authors approved the final version of the manuscript. 


\section{Acknowledgements}

e would like to express our sincere thanks to all stakeholders in this study for their willingness to share their experiences.

\section{References}

1. Starfield B, Shi L, Macinko J. Contribution of primary care to health systems and health. Milbank Q. 2005;83(3):457-502.

https://doi.org/10.1111/j.1468-0009.2005.00409.x

2. Kringos D, Boerma WGW, Hutchinson A, Zee Jvd, Groenewegen PP. The breadth of primary care: a systematic literature review of its core dimensions. BMC Health Serv Res. 2010;10:1-13.

3. Massuda A. Primary health care financing changes in the Brazilian health system: advance ou setback? Ciênc. saude colet. 2020; 25(4): 118188. https://doi.org/10.1590/1413-81232020254.01022020.

4. Russo LX, Powell-Jackson T, Barreto JOM, Borghi J, Kovacs R, Gurgel Junior GD, et al. Pay for performance in primary care: the contribution of the Programme for Improving Access and Quality of Primary Care (PMAQ) on avoidable hospitalisations in Brazil, 2009-2018. BMJ Glob Health. 2021; 6(7):e005429. doi; 10.1136/bmjgh-2021-005429.

5. Castro MC, Massuda A, Almeida G, Menezes Filho NA, Andrade MV, Noronha KVMS, et al. Brazil's unified health system: the first 30 years and prospects for the future. Lancet. 2019; 394:345-56. http://dx.doi.org/10.1016/S0140-6736.

6. Viacava F, Oliveira RAD, Carvalho CC, Laguardia J, Bellido JG. SUS: oferta, acesso e utilização de serviços de saúde nos últimos 30 anos. Ciênc saúde colet. 2018; 23(6):1751-62. https://doi.org/10.1590/1413-81232018236.06022018.

7. Organização Pan-Americana da Saúde. Relatório 30 anos de SUS, que SUS para 2030? Brasília: OPAS; 2018.

8. Tasca R, Massuda A, Carvalho WM, Buchweitz C, Harzheim E. Recomendações para o fortalecimento da atenção primária à saúde no Brasil. Rev Panam Salud Publica. 2020;44:e4. https://doi.org/10.26633/RPSP.2020.4

9. Alkin MC. Evaluation Roots: Tracing theorists' views and influences. Thousand Oaks: Sage; 2004.

10. Avaliação de políticas públicas: guia prático de análise ex Ante. Brasília, DF : Ipea, 2018. v. 1.

11. Ramos MP, Schabbach LM. O estado da arte da avaliação de políticas públicas: conceituação e exemplos de avaliação no Brasil. Rev. Adm. Pública. 2012; 46(5):1271-94. https://doi.org/10.1590/S0034-76122012000500005.

12. Bodstein R, Feliciano K, Hortale VA, Leal MC. Estudos de Linha de Base do Projeto de Expansão e Consolidação do Saúde da Família (ELB/Proesf): considerações sobre seu acompanhamento. Ciênc saúde colet. 2006; 11(3):725-31. https://doi.org/10.1590/S1413-81232006000300019.

13. Silva RR, Gasparini MFV, Gomes PCJC, Akerman M. Avaliação da atenção básica no Brasil: lusco-fusco e aurora. In: Akerman M, Sanine PR, CacciaBava MCG, Marim FA, Louvisan M, Hirooka MB, et al., organizadores. Atenção Básica é o Caminho! Desmontes, Resistências e Compromissos: contribuições das universidades brasileiras para avaliação e pesquisa na APS: perspectivas: avaliação, pesquisa e cuidado em atenção primária a saúde. São Paulo: Hucitec; 2020. p. 21-37.

14. Anjos DSO, Sousa DL, Pereira MF, Teixeira RP, Cantalino JLR. Aprendizados com os ciclos avaliativos do PMAQ-AB e os desafios do novo modelo de avaliação da APS no Brasil. In: Akerman M, Sanine PR, Caccia-Bava MCG, Marim FA, Louvisan M, Hirooka MB, et al., organizadores. Atenção Básica é o Caminho! Desmontes, Resistências e Compromissos: contribuições das universidades brasileiras para avaliação e pesquisa na APS: perspectivas: avaliação, pesquisa e cuidado em atenção primária a saúde. São Paulo: Hucitec; 2020. p. 397-418.

15. Macinko J, Harris MJ, Rocha MG. Brazil's national program for improving primary care access and quality (PMAQ): fulfilling the potential of the world's largest payment for performance system in primary care. J Ambul Care Manage. 2017; 40 suppl 2. doi:10.1097/JAC.0000000000000189.

16. Kayano C, Sanine PR, Louvison M. Contribuições do Programa de Melhoria do Acesso e da Qualidade da Atenção Básica (PMAQ-AB) na produção de conhecimento sobre Atenção Primária em Saúde no Brasil. In: Akerman M, Sanine PR, Caccia-Bava MCG, Marim FA, Louvisan M, Hirooka MB, et al., organizadores. Atenção Básica é o Caminho! Desmontes, Resistências e Compromissos: contribuições das universidades brasileiras para avaliação e pesquisa na APS: perspectivas: avaliação, pesquisa e cuidado em atenção primária a saúde. São Paulo: Hucitec; 2020. p. 72-93.

17. Ministério da Saúde (BR). Portaria GM/MS nº 2.436 de 21/09/2017. Aprova a Política Nacional de Atenção Básica, estabelecendo a revisão de diretrizes para a organização da Atenção Básica, no âmbito do Sistema Único de Saúde (SUS) [Internet]. 2017 [acesso 2022 jan 15]. https://bvsms.saude.gov.br/bvs/saudelegis/gm/2017/prt2436_22_09_2017.html.

18. Melo EA, Mendonça MHM, Oliveira JR, Andrade GCL. Mudanças na Política Nacional de Atenção Básica: entre retrocessos e desafios. Saúde debate. 2018; 42(esp 1):38-51. https://doi.org/10.1590/0103-11042018S103.

19. Facchini LA, Tomasi E, Thumé E, organizadores. Acesso e qualidade na atenção básica brasileira: análise comparativa dos três ciclos da avaliação externa do PMAQ-AB, 2012-2018. São Leopoldo: Oikos; 2021.

20. Morosini MVGC, Fonseca AF, Lima LD. Política Nacional de Atenção Básica 2017: retrocessos e riscos para o Sistema Único de Saúde. Saúde debate. 2018;42(116):11-24. https://doi.org/10.1590/0103-1104201811601

21. Ministério da saúde (BR). Portaria n².979, de 12 de novembro de 2019. Institui o Programa Previne Brasil, que estabelece novo modelo de financiamento de custeio da Atenção Primária à Saúde no âmbito do Sistema Único de Saúde, por meio da alteração da Portaria de Consolidação ${ }^{\circ}$ 6/GM/MS, de 28 de setembro de 2017 [Internet]. 2017 [acesso 2022 jan 15]. Disponível em: https://www.in.gov.br/en/web/dou/-/portaria-n-2.979-de12-de-novembro-de-2019-227652180. 
22. Contandriopoulos AP. Avaliar a avaliação. In: Brousselle A, Champagne F, Contandriopoulos AP, Hartz Z, organizadores. Avaliação: conceitos e métodos. Rio de Janeiro: Fiocruz; 2011. p. 263-272.

23. Elliot LG. Meta-avaliação: das abordagens às possibilidades de aplicação. Ensaio: Aval. pol. públ. Educ. 2011; 19(73):941-64.

24. Tanaka OY, Ribeiro EL, Almeida CAL, editores. Avaliação em Saúde: contribuições para incorporação no cotidiano. 1 ed. Rio de Janeiro: Atheneu; 2017.

25. Stufflebeam DL. Program evaluations meta evaluation - checklist (Based on The Program Evaluation Standards), 1999.

https://wmich.edu/sites/default/files/attachments/u350/2014/program_metaeval_short.pdf. Accessed 01 ago. 2021.

26. Scriven M. Reflections. In: Alkin MC. Evaluation Roots: Tracing theorists' views and influences. Thousand Oaks: Sage; 2004. p.183-95.

27. Centers for Disease Control and Prevention. Introduction to program evaluation for public health programs: A self-study guide. Atlanta, GA: Centers for Disease Control and Prevention; 2011.

28. Yarbrough DB, Hopson RK, Shulha LM, Caruthers FA. The program evaluation standards: a guide for evaluators and evaluation users. Thousands Oaks, CA: Sage; 2011.

29. Centers for Disease Control and Prevention. A Framework for Program Evaluation. 2017. https://www.cdc.gov/eval/framework/index.htm. Accessed 25 nov 2021.

30. Gill S, Kuwahara R, Wilce M. Through a culturally competent lens: Why the program evaluation standards matter. Health Promot Pract. 2016; 17(1):58. doi: 10.1177/1524839915616364.

31. Uchôa SAC, Martiniano CS, Queiroz AAR, Bay Junior OG, Nascimento WG, Diniz IVA, et al. Inovação e utilidade: avaliação externa do Programa Nacional de Melhoria do Acesso e da Qualidade da Atenção Básica. Saúde debate. 2018; 42(esp):100-13.https://doi.org/10.1590/0103-11042018S107

32. Santos PF. Meta-avaliação do programa de melhoria do acesso e qualidade da atenção básica (PMAQ-AB) em Ubajara-CE: um estudo de caso [dissertação]. Sobral: Universidade Federal do Ceará; 2015.

33. Folli SPL. Análise do componente avaliativo do PMAQ na perspectiva de gestores e profissionais de saúde. [dissertação]. Campinas: Universidade Estadual de Campinas; 2016.

34. Yin RK. Estudo de caso: planejamento e métodos. 3. ed. Porto Alegre: Bookman; 2005.

35. Heldler H, Gibram N. The Contributions of Metaevaluation to Program Evaluation: Proposition of a Model. J Multidiscip Evaluation 2009; 6(12):210-223.

36. Uchôa SAC, Rocha PM, Bay Júnior OG, Rocha NSPD, Souza MB, Pinheiro TXA. Modelo de meta-avaliação da Atenção Primária à Saúde: lições aprendidas com a avaliação externa do Programa de Melhoria do Acesso e da Qualidade da Atenção Básica (PMAQ-AB). In: Zulmira Hartz: inovação, humanidade e dinamismo na pesquisa, no ensino, na gestão e na avaliação em saúde. Brasília: Conselho Nacional de Secretários de Saúde; 2021. p. 294-315.

37. Scott J. A matter of record documentary sources in social research. Cambrigde: Polity Press; 1990.

38. Bardin L. Análise de conteúdo. São Paulo: Edições 70; 2011.

39. Ministério da Saúde (BR). Saúde mais perto de você - acesso e qualidade programa nacional de melhoria do acesso e da qualidade da atenção básica (PMAQ): Manual instrutivo. Brasília: Ministério da Saúde; 2012.

40. Ministério da Saúde (BR). Manual instrutivo para as equipes de Atenção Básica e NASF: Programa Nacional de Melhoria do Acesso e da Qualidade da Atenção Básica (PMAQ) - Terceiro ciclo - (2015-2017). Brasília: Ministério da Saúde; 2017.

41. Brucha R, Varsavszky Z. Stakeholver analysis: a review. Health Policy Plan. 2000; 14(3):239-46.

42. Mitchell R, Agle BK, Wood DJ. Toward a Theory of Stakeholder Identification and Salience: Defining the Principle of who and What Really Counts. Acad Manag. 1997; 22(4). https://doi.org/10.5465/amr.1997.9711022105

43. Franco-Trigo L, Fernandez-Llimos F, Martínez-Martínez F, Benrimoj SI, Sabater-Hernández D. Stakeholder analysis in health innovation planning processes: A systematic scoping review. Health Policy. 2020;124(10):1083-99. https://doi.org/10.1016/j.healthpol.2020.06.012

44. Reed MS, Duncan S, Manners P, Pound D, Armitage L, Frewer L, et al. A common standard for the evaluation of public engagement with research'. Research for All. 2018; 2(1):143-62. doi 10.18546/RFA.02.1.13

45. Baron G, Monnier E. Une approche pluraliste et participative: Coproduire l'évaluation avec la société civile. Revue Inf sociales. 2003;(110).

46. Guba EG, Lincoln YS. Fourth generation evaluation. London: Sage Publications; 1989.

47. Furtado J, Vieira-da-Silva LM. A Avaliação de Programas e serviços de saúde no Brasil enquanto espaço de saberes e práticas. Cad. saúde pública. 2014;30(12):2643-55. https://doi.org/10.1590/0102-311X00187113

48. Medeiros GAR, Nickel DA, Calvo MCM. Usos dos resultados da avaliação: revisão integrativa de artigos publicados no período de 2012 a 2016 . Meta: Aval. 2020;12(34):59-87. http://dx.doi.org/10.22347/2175-2753v12i34.2188

49. Cavalcanti P, Fernandez M, Gurgel Júnior GD. Cooperação entre academia e governo para avaliar a Atenção Primária à Saúde no Sistema Único de Saúde. Interface (Botucatu). 2021;25: e210103. https://doi.org/10.1590/interface.210103

50. Ministério da Saúde (BR). Portaria n² 2.488, de 21 de outubro de 2011. Aprova a Política Nacional de Atenção Básica, estabelecendo a revisão de diretrizes e normas para a organização da Atenção Básica, para a Estratégia Saúde da Família (ESF) e o Programa de Agentes Comunitários de Saúde (PACS) [Internet]. 2011 [acesso 2022 jan 28]. Disponível em: https://bvsms.saude.gov.br/bvs/saudelegis/gm/2011/prt2488_21_10_2011.html

51. Bruin SR, Baan C, Struijs JN. Pay-for-performance in disease management: a systematic review of the literature. BMC Health Serv Res. 2011;272:114. http://www.biomedcentral.com/1472-6963/11/272 
52. Van Herk P, De Smedt, Annemans L, Remmen R, Rosenthal MB, Sermeus W. Systematic review: Effects, design choices, and context of pay-forperformance in health care. BMC Health Serv Res. 2010;247:1-13. www.biomedcentral.com/1472-6963/10/247

53. Conrad DA, Perry L. Quality-Based Financial Incentives in Health Care: Can We Improve Quality by Paying for It? Annu Rev Public Heath. 2009;30:35771. doi 10.1146/annurev.publhealth.031308.100243.

54. Kovacs R, Barreto JOM, Silva EN, Borghi J, Kristensen SR, PGradDip DRTC, et al. Socioeconomic inequalities in the quality of primary care under Brazil's national pay-for-performance programme: a longitudinal study of family health teams. Lancet Glob Health. 2021; 9(3):e331-

9. https://doi.org/10.1016/S2214-109X(20)30480-0

55. Macinko J, Harris MJ, Rocha MG. Introduction to the Special Edition on the Brazilian National Program to Improve Primary Care Access and Quality (PMAQ). J Ambul Care Manage. 2017; 40 suppl 2. doi: 10.1097/JAC.0000000000000191.

56. Soares $C$, Ramos M. Uma avaliação dos efeitos do PMAQ-AB nas internações por condições sensíveis à Atenção Básica. Saúde debate. 2020;44(126):708-24. https://doi.org/10.1590/0103-1104202012609

57. Saddi FC, Peckham S. Brazilian Payment for Performance (PMAQ) Seen From a Global Health and Public Policy Perspective. J Ambul Care Manage. 2018;41(1):25-33. https://doi.org/10.1097/JAC.0000000000000220

58. Sanine PR, Paganini LA, Louvison M, Marim FA, Silva LIF, Wilk MCG. Para além da certificação ministerial: como gestores e profissionais de saúde podem utilizar os dados do PMAQ-AB para qualificar as linhas de cuidado. In: Akerman M, Sanine PR, Caccia-Bava MCG, Marim FA, Louvisan M, Hirooka MB, et al., organizadores. Atenção Básica é o Caminho! Desmontes, Resistências e Compromissos: contribuições das universidades brasileiras para avaliação e pesquisa na APS: perspectivas: avaliação, pesquisa e cuidado em atenção primária a saúde. São Paulo: Hucitec; 2020. p. $208-241$.

59. Meloni DR, Dal Fabbro AL. O que um feedback da avaliação de desempenho, via PMAAQ-AB, mobilizou a gestão e nas equipes? In: Akerman M, Sanine PR, Caccia-Bava MCG, Marim FA, Louvisan M, Hirooka MB, et al., organizadores. Atenção Básica é o Caminho! Desmontes, Resistências e Compromissos: contribuições das universidades brasileiras para avaliação e pesquisa na APS: perspectivas: avaliação, pesquisa e cuidado em atenção primária a saúde. São Paulo: Hucitec; 2020. Cap. 5.

60. Hartz ZMA. Avaliação dos programas de saúde. Perspectivas teórico-metodológicas e politicas institucionais. Ciênc. saúde colet. 1999; 4(2):341-53.

61. Felisberto E, Samico I, Bezerra LCA, Hartz Z. Institucionalizando a avaliação nas organizações e agências de pesquisas: um estudo de caso exemplar. Saúde debate. 2017;41(esp): 387-99. https://doi.org/10.1590/0103-11042017S28

\section{Figures}

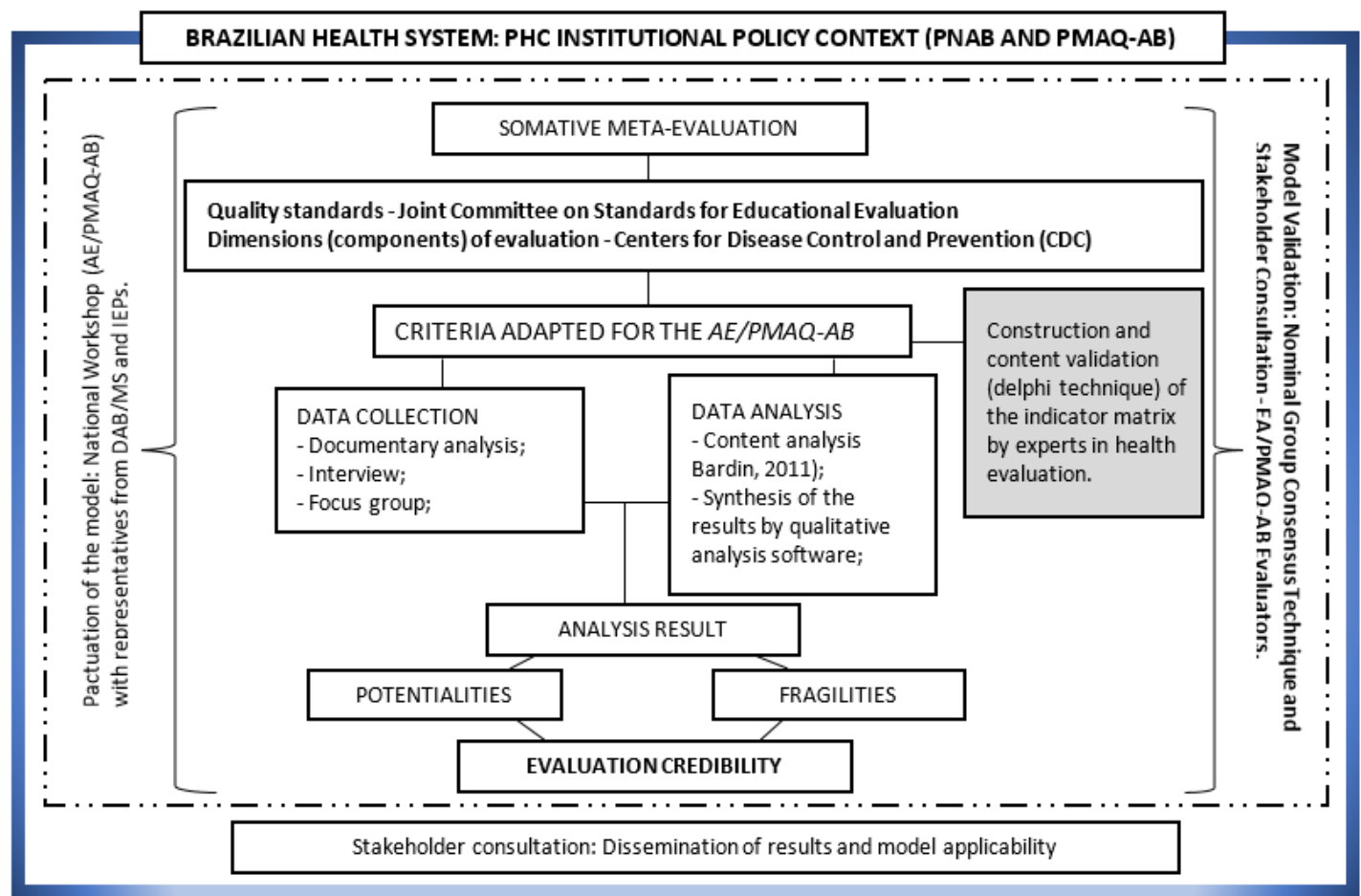

Source: Uchoa [36] (2021).

\section{Figure 1}

Diagram of the PHC Meta-Assessment model applied to $A E / P M A Q-A B$. 


\section{Stage 1}

\begin{tabular}{|c|c|c|c|c|}
\hline $\begin{array}{l}\text { Development of the } \\
A E / P M A Q-A B \text { Quality } \\
\text { Indicator Matrix }\end{array}$ & $\begin{array}{l}\text { Instrument/script } \\
\text { elaboration }\end{array}$ & $\begin{array}{l}\text { Data collection } \\
\text { Documentary analysis }\end{array}$ & $\begin{array}{l}\text { Data collection } \\
\text { Semi-structured } \\
\text { interviews }\end{array}$ & $\begin{array}{l}\text { Data collection } \\
\text { Focus group }\end{array}$ \\
\hline $\begin{array}{l}\text { Elaboration by the group of } 7 \\
\text { researchers - } 04 \text { workshops. } \\
\text { References: } \\
\text { Theoretical assumptions and } \\
\text { design of the } A E / P M A Q-A B ; \\
\text { JCSEE Principles/Standards } \\
\text { (Usefulness; Feasibility; } \\
\text { Property; Accuracy); } \\
\text { CDC Dimensions, 1999: } \\
\text { Stakeholder engagement, } \\
\text { program description, evaluation } \\
\text { design, systematization and } \\
\text { analysis of evidence, } \\
\text { justification of conclusions and } \\
\text { sharing of lessons learned. }\end{array}$ & $\begin{array}{l}\text { Elaboration by the group of } \\
7 \text { researchers - } 04 \\
\text { workshops. } \\
\text { - Document analysis script } \\
\text { - Interview script } \\
\text { - Focus Group script }\end{array}$ & $\begin{array}{l}\text { Document records as a } \\
\text { specific way of } \\
\text { understanding the } \\
\text { contextual reality of } \\
A E / P M A Q-A B \text {. } \\
\text { Inclusion criteria: Official } \\
D A B / M S \text { documentation } \\
\text { published from } 2011 \text { to } \\
2018 \text { and public access. }\end{array}$ & $\begin{array}{l}\text { Conducting } 7 \text { interviews ( } 1 \\
D A B / M S \text { and } 6 \text { with the } \\
\text { general coordination of } \\
\text { each } I E P \text { ) by } 8 \text { trained } \\
\text { interviewers (E1, E2, E3, } \\
\text { E4, E5, E6 and E7). } \\
\text { Recording through digital } \\
\text { recorders and subsequent } \\
\text { transcription. } \\
\text { Contact made by email and } \\
\text { WhatsApp. } \\
\text { Reference: Minayo, } 2010 .\end{array}$ & $\begin{array}{l}\text { Realização de } 7 \text { Grupos } \\
\text { focais por equipe de } \\
\text { pesquisadores } \\
\text { moderador e } 02 \text { relatores) } \\
\text { previamente calibrada. } \\
\text { (1 DAB/MS e } 6 \text { com as IEPs } \\
\text { - GF1 - 9; GF2 }-7 \text {; GF3 }-9 \text {; } \\
\text { GF4-6; GF5 - 8; GF6 - 8 e } \\
\text { GF7 - } 7 \text { da AE/PMAQ-AB, } \\
\text { totalizando } 54 \text { participantes. } \\
\text { Critério de inclusão: } \\
\text { Participantes da AE/PMAQ- } \\
\text { AB escolhidos pelos } \\
\text { coordenadores do DAB e das } \\
\text { IEPs. Registro por meio de } \\
\text { Ragadores digitais e } \\
\text { gravanscrição posterior. } \\
\text { Refrerência: Kitzinger, 2009. }\end{array}$ \\
\hline
\end{tabular}

Validation - Delphi Technique in 2 rounds (2 groups of judges -7 Experts and 16 stakeholders)

Applicability - Pilot study with 12 participants - $P M A Q-A B$ evaluators.

Figure 2

Stages of instrument elaboration and data collection, Natal/RN, 2018 


\begin{tabular}{|c|c|c|}
\hline Pre-Analysis & Material exploration & $\begin{array}{c}\text { Treatment of results, Inference } \\
\text { and Interpretation }\end{array}$ \\
\hline $\begin{array}{l}\text { Record unit - code / Smallest semantic order } \\
\text { cut. } \\
\text { Context unit-citation / Selection of } \\
\text { sentences, excerpts or paragraphs. } \\
\text { Code creation and code group ( } 283 \text { codes) } \\
\text { JCSEE Quality Standards (Usefulness, } \\
\text { Feasibility, Property and Accuracy) and CDC } \\
\text { steps (Stakeholder Engagement, Program } \\
\text { Description, Evaluation Design, } \\
\text { Systematization and Analysis of Evidence, } \\
\text { Justification of Conclusions, and Sharing of } \\
\text { Lessons Learned). } \\
\text { Preparation of an internal manual for } \\
\text { analysis. }\end{array}$ & $\begin{array}{l}\text { Study corpus } \\
\text { Review of transcripts and insertion in Atlas.ti, } \\
\text { identifying each document with the type of } \\
\text { collection carried out (documents and } \\
\text { interviews) - } 21 \text { documents: } 14 \text { equivalent to } \\
\text { interviews and focus groups and } 07 \text { to the } \\
\text { documentary study. } \\
\text { Selection of 'citations' and their linkage to a } \\
\text { specific 'code' -reading strategy by pairs (group } \\
\text { of three researchers), extracting nuclei of } \\
\text { meanings and complementation of previously } \\
\text { established codes, thus ending the process of } \\
\text { registration units. }\end{array}$ & $\begin{array}{l}\text { Generation of specific reports for each } \\
\text { 'group of codes' and submitted to expert } \\
\text { evaluations (three researchers), validating } \\
\text { the relationship betweencitations and codes. } \\
\text { The results were organized into categories } \\
\text { defined a priori and renamed from the field. } \\
\text { Preparation of the research report by the } \\
\text { group of researchers divided into two teams. } \\
\text { Data analysis and interpretation leading to } \\
\text { the elaboration of two Master's dissertations } \\
\text { and two doctoral theses. }\end{array}$ \\
\hline Organization, management and categoriz & textual data was supported by the Atlas ti.8.4.24 & $\begin{array}{r}1 \text { tool (software), under license number 78504- } \\
\text { E7359-3117E-8EB11-0013R. } \\
\text { Source: Research data (2018); Bardin (2011). }\end{array}$ \\
\hline
\end{tabular}

Figure 3

Data analysis stages, Natal/RN, 2018. 